\title{
PENGARUH PENGETAHUAN DAN SIKAP TENTANG KANKER SERVIKS TERHADAP PEMERIKSAAN IVA PADA WANITA USIA SUBUR DI DESA TUNTUNGAN II KECAMATAN PANCUR BATU TAHUN 2013
}

\author{
Melva, Yusrawati Hasibuan, Dewi Meliasari \\ Jurusan Kebidanan Poltekkes Medan
}

\begin{abstract}
Abstrak
Kanker serviks merupakan jenis kanker yang sering terjadi pada wanita, dan merupakan penyebab kematian nomor dua di Indonesia. Kebanyakan pasien datang sudah pada stadium lanjut sehingga penanganan secara medis sulit untuk dilakukan. Salah satu metode alternatif skrining kanker serviks yang dapat dilakukan adalah dengan inspeksi visual dengan pulasan asam setat (IVA). Penelitian ini untuk mengetahuai pengaruh pengetahuan dan sikap tentang kanker serviks terhadap pemeriksaan IVA di Desa Tuntungan Kecamatan Pancur Batu Tahun 2013. Metode penelitian adalah studi analitik observasional dengan rancangan pendekatan crossectional atau studi potong lintang. Populasi penelitian adalah WUS yang ada di Desa sebanyak 500 orang dan sampel penelitian adalah WUS yang pernah melakukan pemeriksaan dan tidak pernah melakukan pemeriksaan IVA dengan jumlah yang sama sebanyak 83 responden. Analisis data menggunakan uji Chi Square dan Regresi Logistik. Hasil penelitian menunjukkan ada pengaruh antara pengetahuan dan sikap terhadap pemeriksaan IVA ( $p=0,046$ dan $p=0,007)$, dah hasil uji multivariat menunjukkan bahwa variabel sikap merupakan variabel dominan dengan nilai Exp (B) 3,424. Hendaknya lebih ditingkatkan lagi pemberian informasi tentang kesehatan reproduksi khususnya tentang deteksi dini kanker servkis. Kepada tenaga kesehatan untuk memberikan informasi dan bahan promosi kesehatan terhadap masyarakat terutama para wanita usia subur dalam rangka meminimalkan kejadian kanker serviks dan dampak yang menyertainya.
\end{abstract}

Kata Kunci : kanker serviks, pemeriksaan IVA

\section{Latar Belakang}

Kanker serviks adalah kanker kedua yang paling umum pada wanita di seluruh dunia, dengan sekitar 500.000 kasus baru dan 250.000 kematian setiap tahun. Hampir 80\% kasus terjadi di Negara berkembang (WHO, 2013).

Kanker serviks menduduki urutan tertinggi di antara Negara berkembang dan urutan ke-10 di Negara maju atau urutan ke- 5 secara global. Menurut data Globocan 2008, terdapat 529.409 kasus baru kanker serviks dengan sekitar 274.883 kematian di dunia. Hampir 85\% kasus terdapat pada negara-negara berkembang.

Di Asia Tenggara, terdapat 188.000 kasus baru kanker serviks, sekitar 102.000 kematian. Di Indonesia, terdapat 13.762 kasus baru dengan kematian 7.493 jiwa dalam setahun. Data dari 13 laboratorium patologi di Indonesia memperlihatkan bahwa kanker serviks menduduki urutan pertama dari 10 kanker terbanyak. (Perhimpunan Onkologi Indonesia, 2010).

Hampir 70\% kanker serviks ditemukan dalam kondisi stadium lanjut (>stadium IIB). Hal ini karena rendahnya pelaksanaan skrining (5\%.) Padahal, pelaksanaan skrining yang ideal adalah $80 \%$. Penduduk Indonesia tahun 2008 yang berjumlah 230 juta. Angka 5\% adalah angka kecil sekali. Padahal, wanita yang beresiko terkena kanker serviks adalah 58 juta (pada usia 15-64 tahun) dan 10 juta (pada usia 10-14 tahun). Jumlah kasus baru kanker serviks mencapai 40-45/hari dan jumlah kematian yang disebabkan kanker serviks mencapai 2025/hari (Samadi, 2011).

Menurut WHO 2008, sekitar 90-99\% penyebab utama terjadinya kanker serviks adalah Human Papiloma Virus (HPV). Dibutuhkan waktu kurang dari tiga bulan dari saat terpapar HPV sampai dapat dideteksi. Setiap wanita beresiko terkena virus HPV, namun infeksi tersebut tidak selalu berkembang menjadi kanker serviks karena sebagian besar infeksi HPV (50-70\%) akan menghilang melalui respon imun alamiah setelah melalui masa beberapa bulan hingga dua tahun. Namun apabila dibiarkan bahkan jika kekebalan tubuh menurun maka virus ini akan berkembang menjadi kanker serviks yang mematikan (Solekhah, 2012).

Penderita kanker serviks sering terlambat ditemukan akibat minimnya gejala yang ditimbulkan karena ketidaktahuan masyarakat. 70\% penderita datang pada stadium lanjut, sehingga menyebabkan masih tingginya angka kematian akibat kanker serviks (Jonathan, 2000). Oleh karena itu perlu dilakukan upaya untuk mendeteksi penyakit ini secara dini, salah satunya adalah dengan metode IVA (Inspeksi Visual Asam Asetat). Pemeriksaan IVA ini merupakan program skrining untuk menemukan tahap prakanker serviks. Hal ini penting karena sampai saat ini masih banyak ditemukan kanker serviks pada stadium lanjut (Samadi, 2011).

Metode IVA pertama kali ditemukan oleh Sankaranarayanan dkk. Deteksi dengan metode IVA ini 
sangat cocok diaplikasikan di Negara berkembang karena mudah, murah, efektif, tidak invasif, dapat dilakukan langsung oleh dokter, bidan atau paramedik. Hasilnya langsung bisa didapat, dan sensitivitas serta spesifitasnya cukup baik.

Pemeriksaan metode IVA mulai dicanangkan di Indonesia oleh Departemen Kesehatan antara tahun 2008 (Solekhah, 2012). Namun sampai saat ini masih banyak kaum wanita yang tidak bersedia melakukan pemeriksaan IVA. Hal ini kemungkinan disebabkan karena kurangnya pengetahuan tentang kanker serviks maupun pemeriksaan IVA serta sikap yang tidak mendukung program pemerintah tersebut.

Survey awal yang dilakukan di desa Tuntungan Kecamatan Pancur Batu tahun 2013 diketahui bahwa dari 500 wanita PUS pada kelompok umur 21 - 45 tahun, hanya 115 orang (23\%) yang mau melakukan pemeriksaan IVA. Berdasarkan data tersebut maka diketahui bahwa partisipasi masyarakat masih rendah.

\section{Permasalahan}

Masih rendahnya partisipasi masyarakat (wanita usia subur) dalam program pemeriksaan IVA sehingga manjadi kendala untuk mendeteksi kanker serviks secara dini.

\section{Tujuan Penelitian}

\section{a. Tujuan Umum:}

Mengetahui Pengaruh Pengetahuan dan Sikap Tentang Kanker Serviks Terhadap Pemeriksaan IVA pada Wanita Usia Subur di Desa Tuntungan Kecamatan Pancur Batu 2013

\section{b. Tujuan Khusus:}

1. Mengetahui distribusi karakteristik (umur, pendidikan) wanita usia subur

2. Mengetahui distribusi pengetahuan wanita usia subur tentang kanker serviks

3. Mengetahui distribusi sikap wanita usia subur tentang kanker serviks

4. Mengetahui pengaruh pengetahuan wanita usia subur terhadap pemeriksaan IVA

5. Mengetahui pengaruh sikap wanita usia subur tentang kanker serviks terhadap pemeriksaan IVA

6. Mengetahui pengaruh variabel dominan terhadap pemeriksaan IVA

\section{Manfaat Penelitian}

a. Hasil penelitian dapat digunakan sebagai bahan pertimbangan dan masukan untuk tenaga kesehatan, khususnya yang berkaitan dengan kesehatan reproduksi b. Untuk meningkatkan pelayanan kesehatan reproduksi pada wanita usia subur khususnya dalam rangka deteksi dini kanker leher rahim.

\section{Hipotesis Penelitian}

a. Ada pengaruh pengetahuan tentang kanker leher rahin terhadap pemeriksaan IVA pada Wanita Usia Subur di Desa Tuntungan Kecamatan Pancur Batu b. Ada pengaruh sikap tentang kanker leher rahim terhadap pemeriksaan IVA pada Wanita Usia Subur di Desa Tuntungan Kecamatan Pancur Batu

\section{Desain Penelitian}

Penelitian ini merupakan studi analitik observasional dengan menggunakan pendekatan desain crossectional akan mengukur seluruh variabel hanya satu kali saja pada saat yang bersamaan ketika penelitian berlangsung di desa Tuntungan II Kecamatan Pancur Batu.

\section{Populasi dan Sampel Penelitian \\ a. Populasi Penelitian}

Populasi pada penelitian ini adalah seluruh wanita usia subur (500 orang) yang telah melakukan pemeriksaan IVA atau belum melakukan pemeriksaan IVA di Desa Tuntungan Kecamatan Pancur Batu yang dilakukan pada bulan April s/d September 2013

\section{b. Sampel Penelitian}

Sampel pada penelitian ini terkait dengan tujuan penelitian adalah bagian dari populasi terjangkau yang dapat dipergunakan sebagai subjek maka jumlah sampel minimal pada penelitian ini adalah 83 orang.

Untuk mendapatkan hasil penelitian yang lebih baik, maka sampel penelitian ditambah dengan responden yang belum pernah dilakukan pemeriksaan tes IVA sebanyak jumlah sampel yang telah dilakukan pemeriksaan tes IVA (83 orang WUS), sehinga total sampel yang diteliti adalah 166 orang.

\section{Hasil Penelitian}

1. Analisis Univariat

a. Karakteristik

Sampel penelitian berjumlah 166 responden terdiri dari ibu yang telah melakukan pemeriksaan IVA dan yang tidak pernah melakukan pemeriksaan IVA dengan jumlah sama, yaitu 83 responden.. Dari hasil pengumpulan dan analisis data maka diperoleh hasil sebagai berikut :

Tabel 1.

Distribusi Responden Berdasarkan Karakteristik di Desa Tuntungan Kecamatan Pancur Batu Tahun 2013

\begin{tabular}{|c|c|c|c|}
\hline No. & Karakteristik & $\begin{array}{l}\text { Jumlah } \\
\text { (n) }\end{array}$ & $\begin{array}{c}\text { Presentase } \\
\text { (\%) }\end{array}$ \\
\hline \multirow[t]{5}{*}{$\overline{1}$} & Pendidikan & & \\
\hline & a. Pendidikan dasar & 90 & 54.2 \\
\hline & b. Pendidikan & 71 & 42.8 \\
\hline & menengah & 5 & 3.0 \\
\hline & $\begin{array}{l}\text { c. Pendidikan } \\
\text { tinggi }\end{array}$ & & \\
\hline \multirow[t]{3}{*}{2.} & Umur & & \\
\hline & a. 21-35 & 62 & 37.3 \\
\hline & b. $35-49$ & 104 & 62.7 \\
\hline \multicolumn{2}{|r|}{ Total } & 166 & 100 \\
\hline
\end{tabular}


b. Pengetahuan

Tabel 2.

Distribusi Responden berdasarkan Pengetahuan di Desa Tuntungan Kecamatan Pancur Batu Tahun 2013

Tingkat pengetahuan Jumlah (n) Presentase (\%)

\begin{tabular}{rlcc} 
a. & Baik & 74 & 44,6 \\
b. & Cukup & 76 & 45,8 \\
c. & Kurang & 16 & 9,6 \\
& & & \\
\hline Total & & 166 & 100 \\
\hline
\end{tabular}

Distribusi responden berdasarkan pengetahuan, proporsi terbesar responden berpengetahuan cukup, yaitu sebesar 45,8\%, dan proporsi terkecil adalah berpengetahuan kurang sebanyak 16 responden $(9,6 \%)$.

\section{c. Sikap}

Tabel 3.

Distribusi Responden berdasarkan Sikap di Desa Tuntungan Kecamatan Pancur Batu Tahun 2013

\begin{tabular}{lcc}
\hline Sikap & $\begin{array}{c}\text { Jumlah } \\
\text { (n) }\end{array}$ & $\begin{array}{c}\text { Presentase } \\
\text { (\%) }\end{array}$ \\
\hline & & \\
Negatif & 42 & 25,3 \\
Positif & 124 & 74,7 \\
& & \\
\hline Total & 166 & 100 \\
\hline
\end{tabular}

\section{d. Jawaban pertanyaan tertutup}

Dalam kuesioner penelitian ini juga ditambahkan pertanyaan tertutup yang diajukan terhadap responden baik yang belum pernah melakukan periksaan ataupun yang sudah pernah melakukan periksa IVA, hasil pengumpulan data tersebut adalah sebagai berikut :

Tabel. 4

Distribusi Jawaban Responden Belum Pernah Melakukan Pemeriksaan IVA

\begin{tabular}{llcc}
\hline No. & \multicolumn{1}{c}{$\begin{array}{c}\text { Alasan Belum Pernah } \\
\text { Periksa IVA }\end{array}$} & n & \% \\
\hline 1. & Tidak pernah ada keluhan & 9 & 10,9 \\
2. & Takut & 40 & 48,2 \\
3. & Tidak tahu & 4 & 4,8 \\
4. & Tidak pernah dengar & 3 & 3,6 \\
5. & Malu tidak ada & 5 & 6,0 \\
6. & Sudah tua dan & 20,5 \\
7. & keluhan & 2 & 2,4 \\
8. & Tidak punya uang/takut mahal & 2 & 2,4 \\
9. & biayanya & 1 & 1,2 \\
\hline & Total sudah meninggal & 83 & 100 \\
\hline
\end{tabular}

Proporsi terbesar tentang alasan responden belum pernah melakukan pemeriksaan test IVA adalah karena takut atau tidak berani untuk melakukan sebanyak 40 responden (49,1\%), disusul karena alasan malu untuk melakukan pemeriksaan sebanyak 17 responden (20,4\%).

Tabel.5

Distribusi Jawaban Responden yang Pernah Melakukan Pemeriksaan IVA

\begin{tabular}{llcc}
\hline No. & Alasan Pernah Periksa IVA & N & \% \\
\hline 1. & $\begin{array}{l}\text { Ingin tahu kondisi } \\
\text { kesehatannya }\end{array}$ & 46 & 55,4 \\
2. & Menjaga kesehatan rahim & 14 & 16,9 \\
3. & Ingin mendeteksi secara dini & 4 & 4,8 \\
4. & Agar merasa nyaman & 5 & 6 \\
5 & Perut sering merasa nyeri & 10 & 13 \\
6. & Sering keputihan dan ada rasa & 4 & 4,8 \\
& gatal & & \\
\hline & Total & 83 & 100 \\
\hline
\end{tabular}

Proporsi terbesar tentang alasan mengapa ibu pernah melakukan pemeriksaan test IVA adalah karena ingin tahu bagaimana kondisi kesehatannya terutama kesehatan rahimnya, yaitu sebanyak 46 responden (56,5\%).

\section{Analisis Bivariat}

Dalam analisis bivariat, dilakukan uji Chi Square untuk melihat pengaruh pengetahuan dan sikap terhadap pemeriksaan IVA. Hasil uji sebagai berikut :

a. Pengaruh Pengetahuan tentang Kanker Serviks terhadap Pemeriksaan IVA pada Wus di Desa Tuntungan Kecamatan Pancur Batu Tahun 2013.

Tabel 6.

Distribusi Responden Menurut Pemeriksaan IVA dan Pengetahuan tentang Kanker Serviks di Desa Tuntungan Kecamatan Pancur Batu Tahun 2013

\begin{tabular}{|c|c|c|c|c|c|c|c|c|}
\hline \multicolumn{2}{|c|}{ Pengetahuan } & \multicolumn{6}{|c|}{ Pemeriksaan IVA } & \multirow{3}{*}{$\boldsymbol{P}$} \\
\hline & & \multicolumn{2}{|c|}{ Belum } & \multicolumn{2}{|c|}{ Sudah } & \multicolumn{2}{|c|}{ Total } & \\
\hline & & $\mathbf{n}$ & $\%$ & $\mathbf{N}$ & $\%$ & $\mathbf{n}$ & $\%$ & \\
\hline a. & Kurang & 12 & 75,0 & 4 & 25,0 & 16 & 100 & \\
\hline b. & Cukup & 40 & 52,6 & 36 & 47,4 & 76 & 100 & 0,046 \\
\hline \multirow[t]{2}{*}{ c. } & Baik & 31 & 41,9 & 43 & 58,1 & 74 & 100 & \\
\hline & Total & 83 & & 83 & & 166 & & \\
\hline
\end{tabular}

Dari total responden yang berpengetahuan kurang, $75 \%$ belum pernah melakukan pemeriksaan IVA, sedangkan dari responden yang berpengetahuan baik 58,1\% sudah pernah melakukan pemeriksaan. Hasil analisis bivariat pengaruh pengetahuan tentang kanker serviks terhadap pemeriksaan Test IVA, diperoleh hasil variabel pengetahuan menunjukkan nilai $p<0,05$ 
( $p=0,046)$, yang dapat diartikan bahwa ada pengaruh variabel pengetahuan terhadap pemeriksaan IVA.

b. Pengaruh Sikap tentang Kanker Serviks terhadap Pemeriksaan IVA pada WUS di Desa Tuntungan Kecamatan Pancur Batu Tahun 2013

Tabel 7.

Distribusi Responden Menurut Pemeriksaan IVA dan Sikap tentang Kanker Serviks di Desa Tuntungan Kecamatan Pancur Batu Tahun 2013

\begin{tabular}{|c|c|c|c|c|c|c|c|}
\hline \multirow{3}{*}{ Sikap } & \multicolumn{6}{|c|}{ Pemeriksaan IVA } & \multirow{3}{*}{$\boldsymbol{P}$} \\
\hline & \multicolumn{2}{|c|}{ Belum } & \multicolumn{2}{|c|}{ Sudah } & \multicolumn{2}{|c|}{ Total } & \\
\hline & $\mathbf{n}$ & $\%$ & $\mathbf{n}$ & $\%$ & $\mathrm{n}$ & $\%$ & \\
\hline Nega & 2 & 69 & 1 & 31 , & & 10 & \\
\hline & 9 & 0 & 3 & 0 & 42 & 0 & 0,00 \\
\hline Positi & 5 & 43, & 7 & 56 , & 12 & 10 & 7 \\
\hline f & 4 & 5 & 0 & 5 & 4 & 0 & \\
\hline Total & 83 & & 83 & & 166 & & \\
\hline
\end{tabular}

Responden yang bersikap negatif, 69\% belum pernah melakukan pemeriksaan IVA, sedangkan dari total responden yang mempunyai sikap positif 56,5\% sudah pernah melakukan pemeriksaan IVA. Hasil analisis bivariat pengaruh sikap tentang kanker serviks terhadap pemeriksaan Test IVA, diperoleh hasil variabel sikap menunjukkan nilai $p<0,05 \quad(p=0,007)$, yang dapat diartikan bahwa ada pengaruh variabel sikap terhadap pemeriksaan IVA.

\section{Analisis Multivariat}

Tabel.8

Analisis Pengaruh Pengetahuan dan Sikap tentang Kanker Servik terhadap Pemeriksaan IVA di Desa Tuntungan II Kec. Pancur Batu Tahun 2013

\begin{tabular}{lllllcc}
\hline \multirow{2}{*}{ Variabel } & \multirow{2}{*}{ B } & \multirow{2}{*}{ S.E } & Wald & df & Value & (B) \\
& & & & & \\
\hline
\end{tabular}

\begin{tabular}{|c|c|c|c|c|c|c|}
\hline Pengetahuan & 0,711 & 0,262 & 7,356 & 1 & 0,007 & 2,035 \\
\hline Sikap & 1,231 & 0,792 & 9,877 & 1 & 0,002 & 3,424 \\
\hline & $-1,889$ & 0,528 & 12,815 & 1 & 0,000 & 0,151 \\
\hline
\end{tabular}

Pada tabel diatas merupakan hasil analisis multivariat dengan uji regresi logistik pada variabel pengetahuan dan sikap. Berdasarkan nilai coeffisien beta (B) yang tertinggi adalah variabel sikap yaitu 1,231. Ini menunjukkan bahwa variabel tersebut merupakan variabel yang paling dominan mempengaruhi pemeriksaan IVA . Besar pengaruh variabel tersebut dapat dilihat dari nilai Exp (B), yaitu 3,424, artinya variabel sikap mempunyai pengaruh 3 kali terhadap pemeriksaan IVA pada responden. Hal ini dapat diartikan bahwa ibu yang mempunyai sikap positif mempunyai peluang 3 kali untuk melakukan pemeriksaan IVA dibandingkan dengan ibu yang sikapnya negatif .

\section{B. Pembahasan}

B1. Pengaruh Pengetahuan Tentang Kanker Serviks Terhadap Pemeriksaan IVA pada Wanita Usia Subur di Desa Tuntungan II Kecamatan Pancur Batu

Proporsi pemeriksaan IVA terbesar terdapat pada kelompok responden dengan pengetahuan kurang (75\%) responden belum pernah melakukan pemeriksaan IVA, sedangkan pengetahuan baik terdapat pada responden yang sudah pernah melakukan pemeriksaan IVA. Penelitian ini sejalan dengan Dewi et all dimana 70,0\% responden dengan pengetahuan kurang tidak melakukan pemeriksaan IVA, sedang tingkat pengetahuan tinggi, cenderung melakukan pemeriksaan IVA.

Penelitian ini juga sesuai dengan pendapat Amiruddin, R, 2006 , pengetahuan yang lebih tinggi sangat berpengaruh dalam mengambil keputusan untuk kesehatannya. Pengetahuan ini juga sejalan dengan pendapat (Arikunto,2003) pendidikan merupakan salah factor yang mempengaruhi pengetahuan, dimana dalam penelitian proporsi terbesar $(54,2 \%)$ dengan pendidikan dasar.

Tingkat pendidikan seseorang dapat mendukung atau mempengaruhi tingkat pengetahuan seseorang , orang dengan pendidikan yang rendah selalu diiringi dengan informasi dan pengetahuan yang terbatas sehingga semakin tingkat pendidikan semakin tinggi pula pemahaman seseorang.

Hal ini juga sejalan dengan alasan responden yang belum pernah melakukan pemeriksaan IVA disebabkan karena takut atau tidak berani (49,1\%). Alasan lain adalah karena responden merasa malu untuk melakukan pemeriksaan IVA (20,4\%), karena harus membuka organ kewanitaannya.

Informasi yang dapat disampaikan dari orang per orang merupakan salah satu factor yang menjadi pertimbangan seseorang dalam menentukan persepsi terhadap sesuatu objek, bila masyarakat kurang mendapat informasi akan mempunyai persepsi ne"gative yang dapat menyebabkan rasa takut dan malu untuk melakukan pemeriksaan IVA.

Pada responden yang pernah melakukan pemeriksaan IVA , proporsi terbesar berpendidikan tinggi dan berpengetahuan baik, dengan alasan ingin tahu kondisi kesehatannya (56,5\%), juga menjaga kesehatan Rahim $(17,4 \%)$.

Penelitian ini juga sejalan dengan penelitian yang dilakukan Bhattcharjee di India, pengetahuan wanita mengenai program screening kanker serviks sangatlah rendah oleh kurangnya informasi. Hal serupa juga didapatkan oleh John yang melakukan penelitian di Rumania, bahwa pengetahuan wanita berusia diatas 18 tahun mengenai skrening kanker serviks sangatlah rendah, hal ini menyebabkan partisipasi untuk melakukan skrening juga rendah, Nurana juga mengemukakan rendahnya pengetahuan wanita mengenai kanker serviks membuat 
rendahnya keinginan perempuan untuk melakukan deteksi dini, hal ini dikarenakan perempuan Indonesia masih awam dengan kanker serviks sehingga berdampak pada rendahnya minat perempuan untuk melakukan deteksi dini kanker serviks.

\section{B.2. Pengaruh Sikap Tentang Kanker Serviks Terhadap Pemeriksaan IVA pada Wanita Usia Subur di Desa Tuntungan Kecamatan Pancur Batu Tahun 2013 \\ Terdapat hubungan yang bermakna dengan} proporsi sikap negatif (69,0\%) pada kelompok belum pernah melakukan pemeriksaan IVA sedangkan responden dengan proporsi sikap positif (56,5\%) pada kelompok yang sudah pernah melakukan pemeriksaan IVA.

Berdasarkan hasil analisis bivariat diperoleh hasil chi-square $\mathrm{p}$ value $\mathrm{p}=0,007$ berarti nilai $\mathrm{p}<0,05$ ada pengaruh sikap terhadap pemeriksaan IVA. Hal ini sejalan dengan hasil penelitian Dewi et All (2012), ada hubungan yang bermakna antara sikap WUS dengan pemeriksaan IVA, dimana WUS yang bersikap negatif belum pernah melakukan pemeriksaan IVA dan WUS dengan sikap positif sudah pernah melakukan pemeriksaan IVA dengan nilai $\mathrm{p}=0,014$.

Penelitian ini juga sejalan dengan hasil penelitian Ninik (2011) terdapat hubungan yang signifikan antara sikap wanita usia subur dalam melakukan pemeriksaan IVA dengan Nilai $\mathrm{P}=0,000$, hasil penelitian Nurtini (2011) juga terdapat hubungan yang signifikan antara factor predisposisi (tingkat pengetahuan dan sikap) wanita usia subur untuk melakukan pemeriksaan IVA dengan nilai $\mathrm{P}=$ 0,000

Dalam menerima suatu kondisi, tidak cukup hanya dengan pengetahuan saja, disamping pengetahuan, adanya respon, rasa tanggung jawab, juga informasi dan pendidikan kesehatan merupakan hal penting dalam mempengaruhi sikap dan persepsi seseorang dalam mempengaruhi perilaku wanita dalam deteksi dini kanker serviks dengan metoda IVA. Penelitian Melva (2008) di RSUP H.Adam malik 91,7 \% penderita kanker serviks tidak pernah melakukan deteksi dini kanker serviks dengan proporsi terbesar pendidikan rendah, ibu umumnya tidak bekerja , informasi yang kurang sehingga ibu tidak mengetahui adanya program deteksi dini kanker serviks dengan test IVA, mudah murah dan efektif, hal ini juga sejalan dengan hasil penelitian Nuranna (2011) 70 \% kasus datang ke rumah sakit sudah dalam kondisi stadium lanjut.

Umumnya kasus kanker cerviks cukup tinggi di Negara berkembang dimana factor penyebabnya adalah sosio ekonomi, datang mencari pengobatan kalau ada perlu atau kalau merasa ada keluhan., selain factor pengetahuan , juga factor budaya dimana dalam penelitian ini alasan responden belum pernah melakukan pemeriksaan test IVA adalah karena merasa takut $(49,1 \%)$ juga merasa malu $(20,4 \%)$, serta tidak pernah ada keluhan .

Hasil penelitian ada hubungan dengan pemeriksaan IVA, dimana proporsi sikap negative (69,0\%) tidak melakukan deteksi dini kanker serviks dengan pemeriksaan IVA ,bila persepsi masyarakat negative akan menjauh untuk melakukan pemeriksaan IVA, hal ini dapat terlihat dengan alasan responden tidak melakukan pemeriksaan IVA karena responden merasa takut, malu, memeriksakan diri bila ada keluhan, atau bila perlu, hal ini juga dipengaruhi oleh kurangnya informasi, pendidikan yang rendah, sehingga persepsi negatif yang dianut masyarakat tentang pemeriksaan IVA akan tetap berakhir pada nilai negative.

Sedangkan sikap positif melakukan pemeriksaan IVA dengan alasan responden melakukan pemeriksaan IVA, proporsi terbesar (56,5\%) ingin mengetahui kondisi kesehatannya, menjaga kesehatan reproduksinya, responden yang melakukan pemeriksaan IVA umumnya berpendidikan tinggi yang berpengaruh terhadap pengetahuan juga mempengaruhi sikap WUS untuk mau melakukan pemeriksaan IVA.

\section{B.3. Pengaruh tingkat pengetahuan dan Sikap WUS tentang kanker Serviks terhadap pemeriksaan IVA.}

Hal ini sesuai dengan hipotesis, ada hubungan pengetahuan dengan pemeriksaan IVA serta hubungan Sikap dengan pemeriksaan IVA, secara signifikan terdapat hubungan pengetahuan dan sikap dalam melakukan deteksi dini kanker serviks dengan pemeriksaan IVA, dimana semakin tinggi tingkat pengetahuan dan sikap maka kemungkinan akan berpengaruh terhadap pemeriksaan IVA.

Hasil analisis variable sikap merupakan factor yang paling berpengaruh terhadap pemeriksaan IVA dengan nilai Exp (B) yaitu 3,424 menunjukkan sikap mempunyai pengaruh 4 kali terhadap pemeriksaan IVA ,artinya wus yang mempunyai sikap positif merupakan factor untuk melakukan pemeriksaan IVA.

Hasil Penelitian ini sejalan dengan penelitian Artiningsih (2011), terdapat hubungan yang simultan antara sikap positif WUS dalam melakukan pemeriksaan IVA, pengetahuan dan sikap berpengaruh terhadap pemeriksaan IVA, penelitian ini juga sejalan dengan penelitian Dewi (2011), terdapat hubungan positif antara tingkat pengetahuan dan sikap WUS dengan melakukan pemeriksaan IVA.

\section{A. Kesimpulan}

Berdasarkan hasil analisis dan pembahasan hasil penelitian, dapat diambil beberapa kesimpulan mengenai pengaruh pengetahuan dan sikap tentang kanker serviks terhadap pemeriksaan IVA di Desa Tuntungan II Kec Pancur Batu tahun 2013.

1. Karakteristik responden proporsi terbesar berpendidikan dasar (54,2\%), dan umur responden pada kelompok 35 - 49 thn (62,7\%).

2. Pengetahuan responden proporsi terbesar berpengetahuan cukup (45,8\%)

3. Sikap responden proporsi terbesar bersikap positif (74,7\%).

4. Adanya pengaruh antara pengetahuan WUS terhadap pemeriksaan IVA $(p=0,046)$, semakin tinggi pengetahuan 
WUS maka semakin tinggi perilaku pemeriksaan.

5. Adanya hubungan antara sikap terhadap pemeriksaan IVA $(p=0,007)$ semakin baik sikap WUS, maka semakin positif perilaku pemeriksaan WUS

6. Sikap merupakan variabel yang paling berpengaruh terhadap pemeriksaan IVA $(p=0,002)$.

Saran

1. Kepada petugas kesehatan (bidan) untuk lebih meningkatkan lagi pemberian informasi pentingnya deteksi dini kanker serviks dengan test IVA

2. Memasyarakatkan salah satu program pelaksanaan deteksi dini kanker serviks dengan test IVA.

3. Perlunya dukungan dari Departemen Agama, tokoh masyarakat, juga peran serta masyarakat yang dapat memberikan informasi, kepada masyarakat untuk memelihara kesehatan reproduksinya dengan melakukan deteksi dini kanker servik dengan pemeriksaan IVA.

4. Perlunya membudayakan pendidikan lebih awal tentang anatomi kesehatan reproduksi sehingga bisa merubah paradigma tentang kesehatan reproduksi di kemudian hari.

\section{DAFTAR PUSTAKA}

Artiningsih, A, 2011, Hubungan antara Pengetahuan dan Sikap WUS dengan Pemeriksaan IVA dalam Rangka Deteksi Dini Kanker Serviks di Wilayah Puskesmas Blooto Kota Mojokerto, Tesis, Pasca Sarjana Kedokteran Keluarga, UNS

Aziz, Farid M, 2002 Deteksi Dini Kanker , Skrining dan Deteksi Dini Kanker Serviks : ed Ramli Muchils, Umbas Rainy, Panigoro S.Sonar, Fakultas Kedokteran Universitas Indonesia Jakarta;97-110

Budiarto E, 2001 Biostatistika Untuk Kedokteran dan Kesehatan Masyarakat, Jakarta, EGC, Cetakan I

Chabaud M, Munoz N, coottu C, Coursaget P, Anthonioz P, day N, et al, 1994 Human Papiloma Virus Infection in Women With Cervical Cancer in:
Stanley Ma, ed. Immunology of human papiloma viruses (HPVS). New York

EdiEdiannto Deri, 2008. Kanker Serviks, Buku Acuan Nasional: ed Aziz Farid, Andrijono, Saifuddin Bari A, Yayasan Bina Pustaka Sarwono Prawiro Harjo

Hoskin J,Willem, Peres,Carlos A, Robert C, Young, 2000 Principle and Practice of Gynecologic Oncology 3 ed. PhiladelphiaLippincot - Raven;12-18;726733.

Jonathan S.Berek, Neville F.Hacker, 2000, Practical Gynecologic Oncologic Third Edition Lippincott Wiliam, Philadelphia;349.

Murhti Bisma, 1995 Prinsip dan Metode Riset Epidemiologi, Universitas Gajah Mada Press.

Notoatmadjo, S, 2002 Metodologi Penelitian Kesehatan, Edisi Revisi Rineke Cipta Jakarta.

Puspita, Y, dkk, 2011, Hubungan Tingkat Pendidikan dan Pengetahuan Ibu tentang Kanker Serviks dengan Pemeriksaan Pap Smear di Wilayah Kerja Puskesmas Pegandan, Kota Semarang

Riono, Yohanes, 1999 Kanker Leher Rahim, Dept of Sugery Holliwood Hospital, Australia,;1-4.

Samadi, H.P, 2011, Yes, I Know Everything about Canker Cerviks $<$ Metagraf, Solo

Scaraberg, 1985 Karsinoma Serviks Uteri Dalam Onkologi, Penerbit Pustaka Jakarta.

Soebachman, A, 2011, Awas 7 Kanker paling Mematikan !, Syura Media Utama, Yogyakarta

Solekhah, S, 2012, Hubungan antara KarakteristikWanita terhadap Kesadaran terhadap Inspeksi Visual dengan Asam Asetat (IVA) di Wilayah kerja Puskesmas Jekulo Kudus, Jurnal

Sri Dewi, N, 2012, Hubungan antara pengetahuan dan Sikap Wanita Usia Subur dengan Pemeriksaan Inspeksi Visual Asam Asetat di Puskesmas Buleleng I, Tesis, Pasca Sarjana Kedokteran Keluarga, USM Surakarta

Tara Elizabeth MD, 2001 Kanker pada Wanita, Panduan Lengkap Pencagahan dan Pengendalian Kanker pada Wanita. Penerbit Ladang Pustaka dan Intimedia.1,26,30,35,46,76.

Tri Kusuma, R, Pengaruh Pendidikan Kesehatan terhadap Perubahan Perilaku Wanita dalam Pemeriksaan Dini Kanker Serviks Menggunakan Metoda Inspeksi Visual Asam Asetat 